\title{
Rancang Bangun Sistem Pendeteksi Bump Menggunakan Android Smartphone dengan Sensor Akselerometer
}

\author{
Otniel Yehezkiel Bornok Hutabarat, Fajar Baskoro, dan Rizky Januar Akbar \\ Jurusan Teknik Informatika, Fakultas Teknologi Informasi, Institut Teknologi Sepuluh Nopember \\ Jl. Arief Rahman Hakim, Surabaya 60111 Indonesia \\ e-mail: fajar@its-sby.edu
}

\begin{abstract}
Abstrak-Seiring semakin meningkatnya jumlah polisi tidur yang ilegal atau tanpa izin, maka hal ini dapat menyebabkan ketidaknyamanan oleh pengguna jalan. Selain itu berbagai kerusakan jalan seperti lubang dan gundukan juga mengganggu kenyamanan pengguna jalan. Pemerintah juga telah membuat sanksi yang ditulis dalam Peraturan Daerah terhadap pembuat pita penggaduh atau polisi tidur yang tidak memiliki izin dari Kepala Dinas Perhubungan. Untuk mengatasi masalah tersebut, pada penelitian ini dibangun sebuah sistem pendeteksi bump yang terdiri dari aplikasi Android dan peta digital. Pada aplikasi Android, sistem mengumpulkan data dengan mendeteksi guncangan apabila pengguna melewati polisi tidur, lalu mengirim lokasi tersebut ke server. Deteksi guncangan ini memanfaatkan sensor akselerometer pada Android dan pengiriman lokasi menggunakan GPS. Kemudian pada server data diolah dan ditampilkan dalam bentuk peta digital. Setelah melakukan pengujian, data yang dihasilkan adalah lokasi guncangan (disebabkan oleh polisi tidur atau jalan rusak) dan ditampilkan dalam bentuk peta digital dengan akurasi rata-rata $89,48 \%$. Dengan adanya sistem ini, diharapkan informasi lokasi guncangan (polisi tidur maupun kerusakan jalan yang terdeteksi) dapat diperoleh secepat mungkin sehingga pemerintah dapat bertindak dengan lebih cepat dan efektif.
\end{abstract}

Kata Kunci-Deteksi Bump, Monitor Jalan, Perangkat Bergerak, Sensor Android

\section{PENDAHULUAN}

$\mathrm{P}$ OLISI tidur adalah bagian jalan yang ditinggikan berupa tambahan aspal atau semen yang dipasang melintang di jalan untuk pertanda meperlambat laju/kecepatan kendaraan. Tujuan utama dari polisi tidur sendiri adalah untuk mencegah terjadinya kecelakaan pada saat aktivitas transportasi. Polisi tidur banyak ditemukan di daerah pemukiman penduduk, perumahan, terminal atau pasar. Namun pada kenyataannya banyak sekali polisi tidur yang dibuat tidak sesuai dengan desain polisi tidur yang diatur berdasarkan Keputusan Menteri Perhubungan No. 3 Tahun 1994 sehingga dapat membahayakan keamanan dan kenyamanan pengguna jalan.

Salah satu pendekatan untuk mengidentifikasi polisi tidur yang memiliki izin adalah adanya laporan dari pihak pembuat polisi tidur dengan pihak yang berwenang. Untuk setiap daerah memiliki peraturan masing-masing untuk menindaklanjuti Keputusan Menteri Perhubungan tersebut. Misalnya untuk daerah Jakarta diatur oleh Peraturan Daerah Provinsi DKI yaitu berdasarkan pasal 53 huruf b Perda DKI Jakarta 12/2003, setiap orang tanpa izin dari Kepala Dinas Perhubungan dilarang membuat atau memasang tanggul pengaman jalan dan pita penggaduh (speed trap). Pelanggaran terhadap ketentuan tersebut adalah kurungan paling lama 3 bulan atau denda sebanyak-banyaknya Rp5.000.000,00 (lima juta rupiah). Oleh karena itu, untuk mempermudah pemerintah mengetahui polisi tidur yang memiliki izin atau ilegal, pada penelitian ini saya menawarkan sistem pendeteksi bump menggunakan smartphone Android dengan pendekatan survei otomatis.

Berdasarkan penelitian sebelumnya yang telah dilakukan adalah Pothole Patrol (P2) [1], menggunakan sensor 3-axis accelerometer dan GPS diletakkan pada kendaraan taksi untuk memonitor keadaan permukaan jalan. Pothole Patrol dapat mendeteksi lubang dan anomali jalan dengan cara mengolah data dari getaran atau vibrasi pada akselerometer dan GPS. Penelitian ini juga mengklasifikasi data berdasarkan lokasi untuk mengurangi kesalahan dalam.

Pada penelitian selanjutnya yaitu CRSM [2] atau disebut juga crowdsourcing-based road surface monitoring system mampu mendeteksi lubang dan mengevaluasi tingkat kekasaran permukaan jalan. Penelitian yang menggunakan sensor smartphone adalah Wolverine [3]. Wolverine menggunakan sensor akselerometer untuk mengumpulkan data untuk mendeteksi event bump dan rem. Perangkatnya direorientasi terlebih dahulu sehingga dapat digunakan pada posisi apapun di dalam kendaraan. Proses reorientasinya menggunakan sensor akselerometer dan magnometer. Data akselerometer yang dikumpulkan kemudian diolah menggunakan Support Vector Machine (SVM) untuk menentukan kondisi jalan mulus atau bergelombang dan kondisi rem atau tidak. Salah satu penelitian yang mendeteksi lubang secara real time adalah Mednis, [4] penelitian tersebut mengusulkan sistem yang menggunakan smartphone Android beserta sensor akselerometernya untuk mendeteksi events secara real time. Sistem ini mengumpulkan data secara off-line post-processing dengan menggunakan algoritma Z-Thresh, Z-Diff, STDEV(Z) dan G-Zero.

Pendekatan survei otomatis yang diusulkan pada penelitian ini dapat dilakukan dengan menggunakan embedded sensing devices atau smartphone. Pada penelitian ini akan berfokus pada proses data akselerometer untuk mendeteksi bump 
menggunakan smartphone Android. Metode untuk mendeteksi bump menggunakan kombinasi metode real-time dan nonrealtime. Metode real-time menggunakan algoritma Z-Thresh seperti pada penelitian pada Mednis et al namun perbedaannya adalah pada penelitian ini juga menggunakan metode klasifikasi decision tree pada data yang terdeteksi menggunakan algoritma Z-Thresh di server untuk menghasilkan deteksi yang lebih akurat. Data GPS lokasi polisi tidur akan dikirim dari smartphone Android ke server.

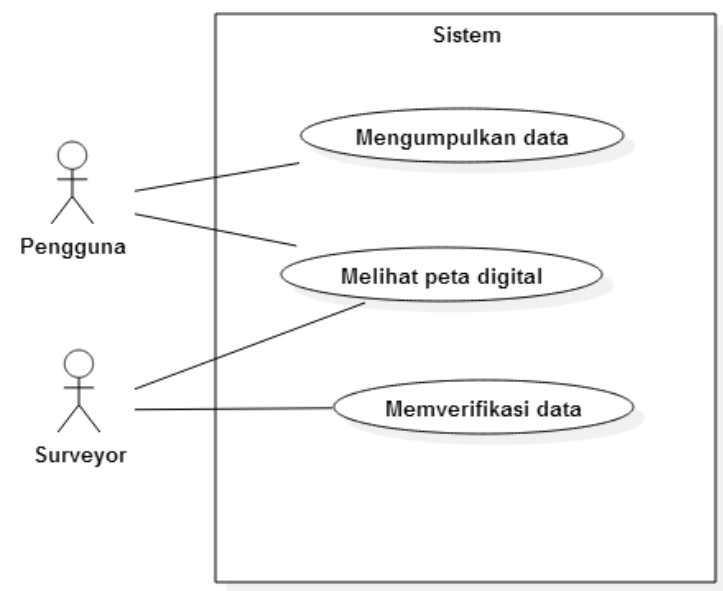

Gambar 1 Diagram kasus penggunaan

Data-data GPS lokasi polisi tidur yang dikirim dari para pengguna diolah untuk mengestimasi lokasi polisi tidur dengan lebih akurat dan ditampilkan dalam bentuk peta digital. Dengan sistem yang crowdsourced (menggunakan kumpulan data partisipasi yang terdistribusi) dapat meningkatkan skalabilitas melihat banyaknya jumlah pengguna smartphone dan terus meningkat. Harapannya adalah informasi tersebut dapat diperoleh sedini mungkin sehingga dapat digunakan pemerintah untuk mempermudah pengawasan pembuatan polisi tidur maupun perbaikan dan pemeliharaan jalan.

\section{URAIAN PENELITIAN}

\section{A. Kasus Penggunaan}

Error! Reference source not found. menunjukkan diagram kasus penggunaan dari aplikasi. Kasus penggunaan pada aplikasi ini adalah mengumpulkan data oleh pengguna, melihat peta digital dan memverifikasi data oleh surveyor.

\section{B. Algoritma Z-Tresh}

Algoritma Z-Thresh merupakan algoritma yang melakukan thresholding pada nilai amplitudo akselerometer di sumbu z. Event direpresentasikan sebagai nilai yang melebihi ambang batas atau threshold yang ditentukan. Masukan berupa data akselerometer pada sumbu x, y dan z. Keluaran berupa informasi apakah terdeteksi bump atau bukan bump. Diagram alir algoritma Z-thresh dapat dilihat pada Gambar 2.

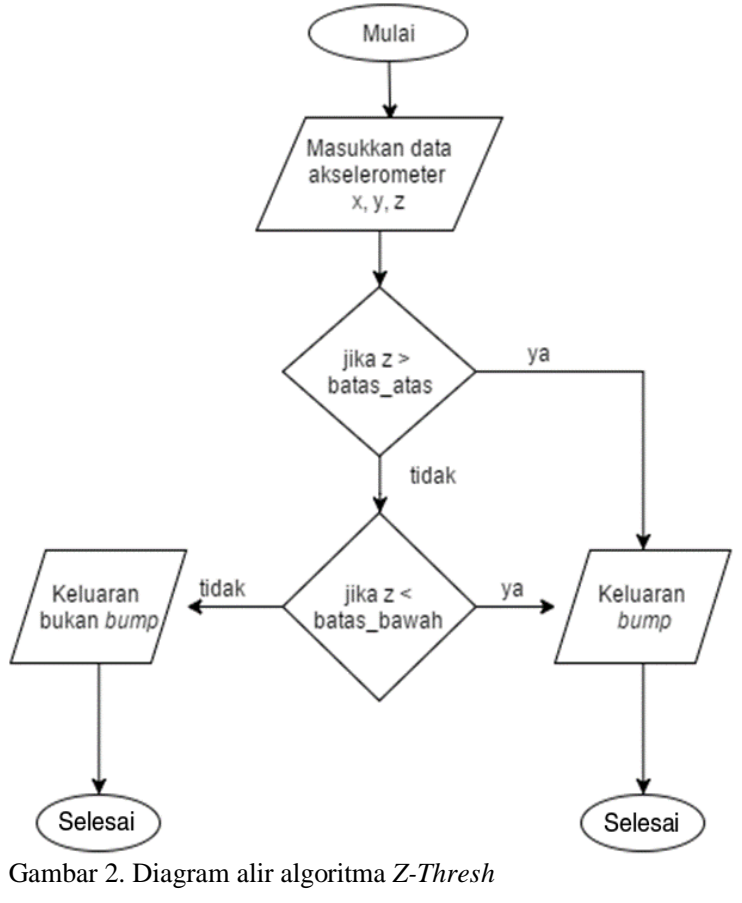

\section{Reorientasi Sistem Koordinat Sensor}

Sensor akselerometer Android memiliki sistem koordinat yang relatif terhadap perangkat Android itu sendiri. Apabila perangkat tersebut bergerak atau disorientasi maka dapat mempersulit pengukuran data akselerometer. Untuk itu diperlukan suatu mekanisme yang dapat melakukan reorientasi dari sistem koordinat perangkat menjadi sistem koordinat pada kendaraan. Metode reorientasi dijelaskan pada penelitian Wolverine.

\section{BIRCH Clustering}

BIRCH (Balanced Iterative Reducing and Clustering using Hierarchies) merupakan algoritma unsupervised machine learning yang melakukan hierarchical clustering pada dataset yang besar [5].

\section{E. Decision Tree}

Decision tree adalah metode klasifikasi yang mengubah data menjadi pohon keputusan dan aturan keputusan. Decision tree atau pohon keputusan juga memperhatikan faktor-faktor kemungkinan yang mempengaruhi proses pengambilan keputusan tersebut. Algoritma yang digunakan pada decision tree ini adalah CART algorithm [6].

\section{F. Proses Data}

Data yang dikirimkan berupa JSON berisi data akselerometer dan lokasi GPS. Pengiriman data JSON dari smartphone menuju server terjadi setiap kali terjadi event yakni ketika pengendara mengalami lonjakan pada jalan.

Data yang dikirim adalah hasil data yang terekam selama 1,5 detik setiap terjadi event. Data tersebut kemudian diprediksi menggunakan klasifikasi dengan metode decision tree. Apabila benar maka lokasi data tersebut akan ditampilkan pada peta digital. 


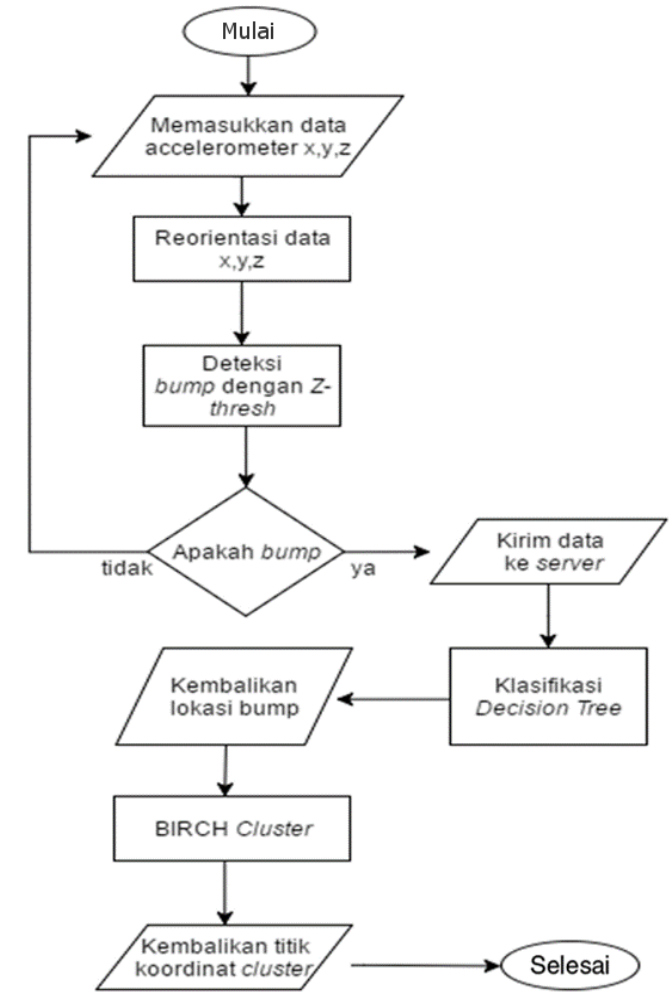

Gambar 3. Diagram alir proses data

Tabel 1.

Rangkuman hasil uji coba fungsionalitas

\begin{tabular}{cc}
\hline \hline Nama Kasus Penggunaan & Hasil \\
\hline Melihat peta digital & Berhasil \\
Mengumpulkan data & Berhasil \\
Memverifikasi data & Berhasil \\
\hline \hline
\end{tabular}

Pada peta digital koordinat lokasi polisi tidur juga akan dicluster untuk titik-titik yang berdekatan (kurang dari 5-9 meter) menggunakan clustering dengan algoritma BIRCH. Diagram alir perancangan proses data ditunjukkan pada Gambar 3.

\section{HASIL DAN PEMBAHASAN}

\section{A. Uji Fungsionalitas}

Uji coba fungsionalitas adalah uji coba fungsi-fungsi yang berjalan pada aplikasi. Pengujian dilakukan oleh pengguna dengan tujuan untuk menjalankan aplikasi pemetaan lokasi bump dan melihat hasilnya peta digital. Hasil pengujian fungsionalitas dapat dilihat pada Tabel 1 .

Hasil tampilan melihat peta digital ditunjukkan pada Gambar 4.

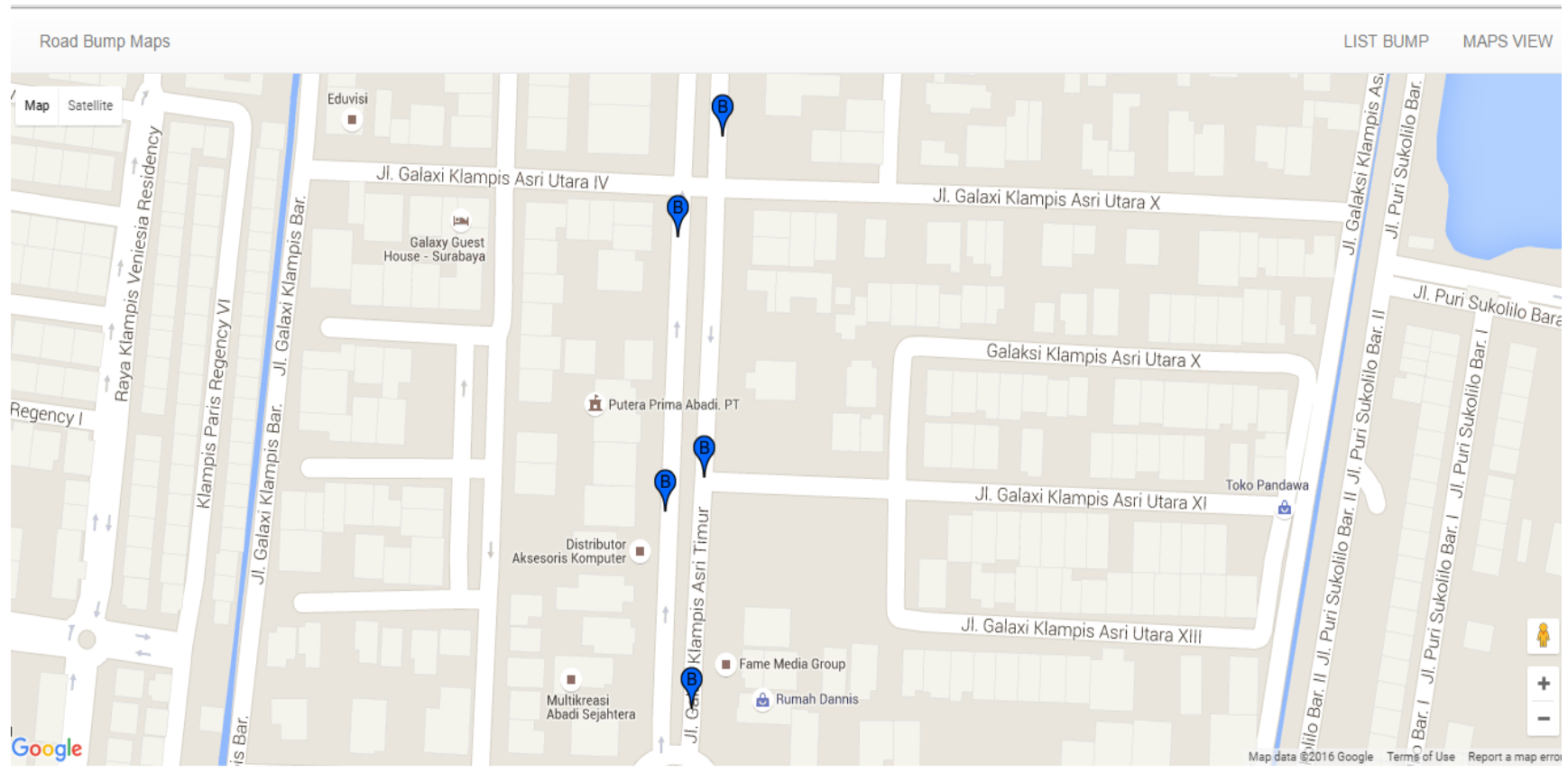

Gambar 4. Tampilan lokasi bump pada peta digital

Tampilan antarmuka utama aplikasi Android saat mengumpulkan data dapat dilihat pada Gambar 5. Pada layar Android ditampilkan nilai akselerometer, nilai latitude dan longitude, beserta jumlah bump yang telah diperoleh.
Gambar 6 menunjukkan tampilan pada halaman verifikasi data dapat. Pada halaman ini terdapat informasi grafik akselerasi pada bump beserta form untuk memilih jenis bump. 


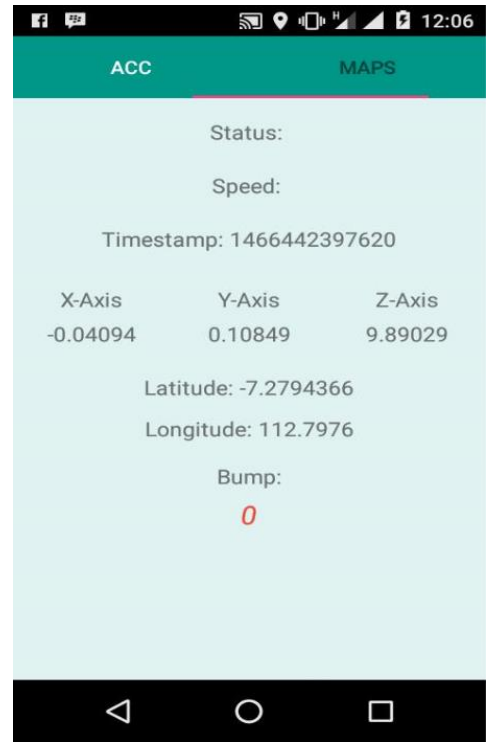

Gambar 5. Tampilan antarmuka utama aplikasi Android

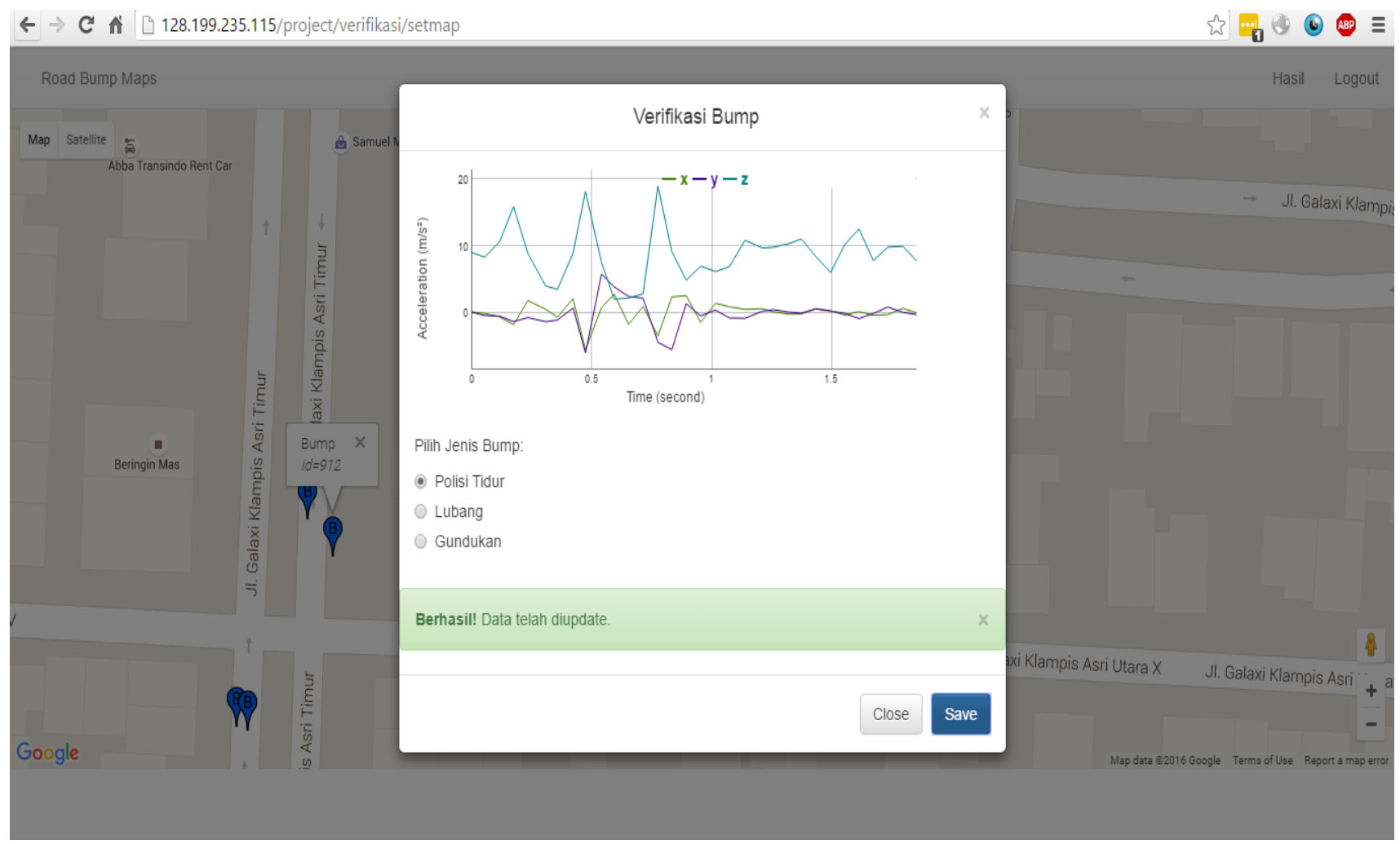

Gambar 6. Tampilan halaman verifikasi data

\section{B. Analisa Data}

Data akselerometer yang dianalisa adalah nilai yang diamati ketika pengendara melewati polisi tidur. Pada Gambar 7 menunjukkan nilai akselerometer pada saat melewati polisi tidur dengan kecepatan konstan $20 \mathrm{~km} / \mathrm{jam}$. Dapat dilihat nilai yang paling berpengaruh adalah nilai akselerasi pada sumbu $z$ hal ini disebabkan saat melewati polisi tidur, kendaraan akan mengalami guncangan naik turun sebanyak dua kali.

Guncangan pertama pada titik A Gambar 7 adalah guncangan akibat roda depan motor mengenai polisi tidur kemudian pada titik B adalah guncangan akibat roda belakang motor mengenai polisi tidur. Berdasarkan analisa ini maka pendeteksian bump dapat menggunakan algoritma Z-Thresh, yaitu mendeteksi terjadinya bump ketika nilai akselerometer pada sumbu $z$ telah melewati nilai threshold tertentu. 

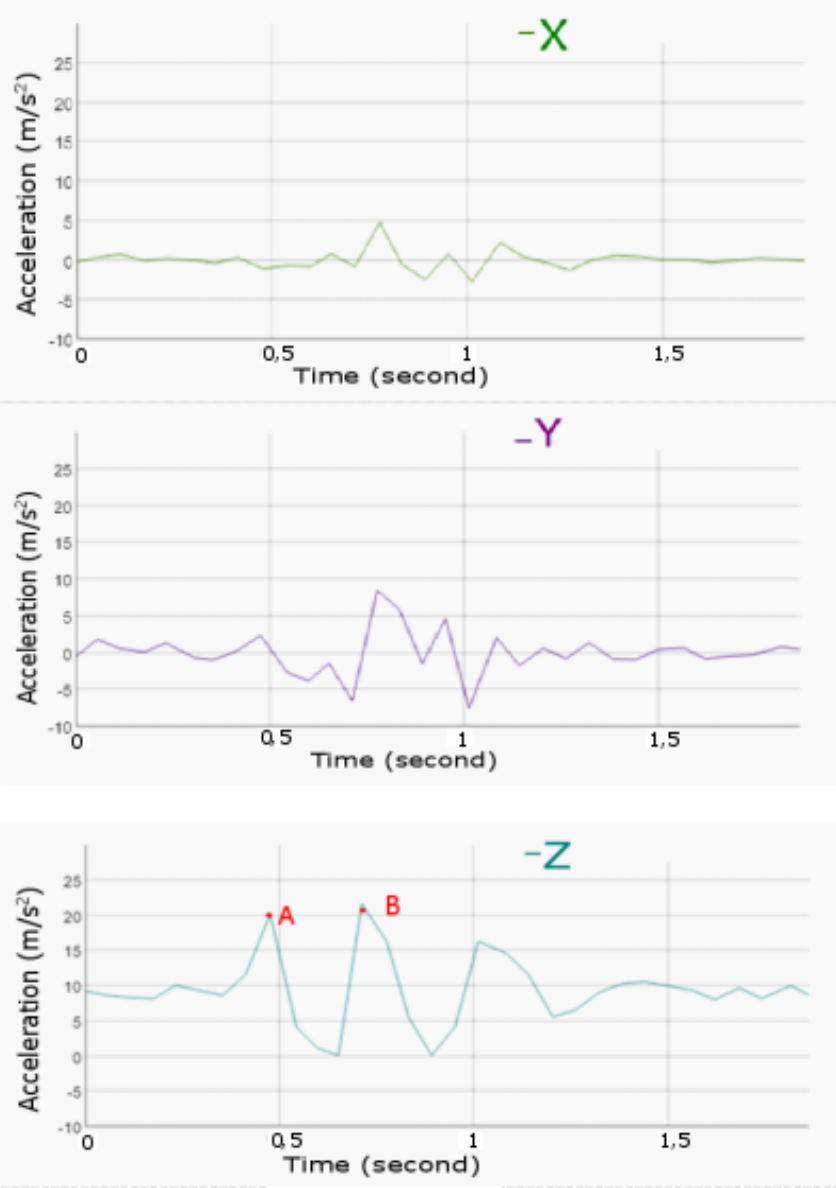

Gambar 7 Grafik data akselerometer pada polisi tidur

Tabel 2.

Tata cara pengujian

1. Perumahan Galaxi Klampis $(2.61 \mathrm{~km})$. Total bump $=12$. Jenis jalan paving.

2. Perumdos Blok U, dari Jalan Teknik Mesin sampai Blok U $(1.11 \mathrm{~km})$. Total bump $=10$. Jenis jalan paving.

3. Jalan Semolowaru $(1.47 \mathrm{~km})$. Total bump $=7$. Jenis jalan aspal.

Metode yang Diuji

1. Z-Thresh

2. Decision tree

Posisi Peletakan 1. Kantong baju

Smartphone

2. Tas

3. Dipegang

1. Pelan $(5-15 \mathrm{~km} / \mathrm{jam})$

Kecepatan

2. Sedang $(15-30 \mathrm{~km} / \mathrm{jam})$

3. Cepat (lebih dari $35 \mathrm{~km} / \mathrm{jam})$

\section{Pengujian Akurasi}

Uji coba akurasi deteksi polisi tidur dilakukan untuk mengetahui akurasi aplikasi dalam mendeteksi bump. Tata cara pengujian akurasi dijelaskan pada Tabel 2.

Pada Tabel 3 dapat dilihat skenario pengujian yang dilakukan. Skenario pengujian P-01 sampai P-09 diujikan untuk mengetahui pengaruh posisi smartphone terhadap akurasi aplikasi.

Pengujian P-15 sampai P-24 untuk mengetahui pengaruh kecepatan (cepat, sedang dan pelan) terhadap akurasi. Pengujian P-10 sampai P-15 dilakukan untuk mencari threshold yang lebih akurat.
Pengujian P-25 sampai P-30 dilakukan untuk menguji metode klasifikasi decision tree dapat meningkatkan akurasi atau tidak. Lokasi GK adalah Galaksi Kelampis sedangkan JS adalah Jalan Semolowaru.

Tabel 3.

Skenario pengujian

\begin{tabular}{cccccc}
\hline $\begin{array}{c}\text { Pengu- } \\
\text { jian }\end{array}$ & Lokasi & $\begin{array}{c}\text { Z- } \\
\text { Thresh }\end{array}$ & $\begin{array}{c}\text { Decis- } \\
\text { ion tree }\end{array}$ & $\begin{array}{c}\text { Kecep- } \\
\text { atan }\end{array}$ & $\begin{array}{c}\text { Peletakan } \\
\text { Smartphone }\end{array}$ \\
\hline P-01 & G. K. & $18 / 2$ & - & sedang & k. baju \\
P-02 & G. K. & $18 / 2$ & - & sedang & tas \\
P-03 & G. K. & $18 / 2$ & - & sedang & k. baju \\
P-04 & J. S. & $18 / 2$ & - & sedang & k. baju \\
P-05 & J. S. & $18 / 2$ & - & sedang & tas \\
P-06 & J. S. & $18 / 2$ & - & sedang & dipegang \\
P-07 & Blok-U & $18 / 2$ & - & sedang & k. baju \\
P-08 & Blok-U & $18 / 2$ & - & sedang & tas \\
P-09 & Blok-U & $18 / 2$ & - & sedang & dipegang \\
P-10 & G. K. & $18 / 2$ & - & sedang & k. baju \\
P-11 & G. K. & $17 / 3$ & - & sedang & k. baju \\
P-12 & J. S. & $18 / 2$ & - & sedang & k. baju \\
P-13 & J. S. & $17 / 3$ & - & sedang & k. baju \\
P-14 & Blok-U & $18 / 2$ & - & sedang & k. baju \\
P-15 & Blok-U & $17 / 3$ & - & sedang & k. baju \\
P-16 & G. K. & $17 / 3$ & - & cepat & k. baju \\
P-17 & G. K. & $17 / 3$ & - & sedang & k. baju \\
P-18 & G. K. & $17 / 3$ & - & pelan & k. baju \\
P-19 & J. S. & $17 / 3$ & - & cepat & k. baju \\
P-20 & J. S. & $17 / 3$ & - & sedang & k. baju \\
P-21 & J. S. & $17 / 3$ & - & pelan & k. baju \\
P-22 & Blok-U & $17 / 3$ & - & cepat & k. baju \\
P-23 & Blok-U & $17 / 3$ & - & sedang & k. baju \\
P-24 & Blok-U & $17 / 3$ & - & pelan & k. baju \\
P-25 & G. K. & $17 / 3$ & - & sedang & k. baju \\
P-26 & G. K. & $17 / 3$ & $\checkmark$ & sedang & k. baju \\
P-27 & J. S. & $17 / 3$ & - & sedang & k. baju \\
P-28 & J. S. & $17 / 3$ & $\checkmark$ & sedang & k. baju \\
P-29 & Blok-U & $17 / 3$ & - & sedang & k. baju \\
P-30 & Blok-U & $17 / 3$ & $\checkmark$ & sedang & k. baju \\
\hline & & & & & \\
\hline
\end{tabular}

Tabel 4.

Hasil uji coba

\begin{tabular}{cccccc}
\hline \hline $\begin{array}{c}\text { Kode } \\
\text { Pengujian }\end{array}$ & $\begin{array}{c}\text { True } \\
\text { Positives }\end{array}$ & $\begin{array}{c}\text { False } \\
\text { Positives }\end{array}$ & $\begin{array}{c}\text { False } \\
\text { Negatives }\end{array}$ & Presisi & $\begin{array}{c}\text { Sensitivi- } \\
\text { tas }\end{array}$ \\
\hline P-01 & 10 & 0 & 2 & $100,00 \%$ & $83,33 \%$ \\
P-02 & 12 & 3 & 4 & $80,00 \%$ & $75,00 \%$ \\
P-03 & 5 & 2 & 7 & $71,43 \%$ & $41,67 \%$ \\
P-04 & 6 & 0 & 0 & $100,00 \%$ & $100,00 \%$ \\
P-05 & 6 & 1 & 0 & $85,71 \%$ & $100,00 \%$ \\
P-06 & 6 & 5 & 0 & $54,55 \%$ & $100,00 \%$ \\
P-07 & 9 & 0 & 1 & $100,00 \%$ & $90,00 \%$ \\
P-08 & 9 & 4 & 1 & $69,23 \%$ & $90,00 \%$ \\
P-09 & 4 & 0 & 5 & $100,00 \%$ & $44,44 \%$ \\
P-10 & 10 & 0 & 2 & $100,00 \%$ & $83,33 \%$ \\
P-11 & 12 & 1 & 0 & $92,31 \%$ & $100,00 \%$ \\
P-12 & 6 & 0 & 0 & $100,00 \%$ & $100,00 \%$ \\
P-13 & 6 & 0 & 0 & $100,00 \%$ & $100,00 \%$ \\
P-14 & 9 & 0 & 1 & $100,00 \%$ & $90,00 \%$ \\
P-15 & 10 & 2 & 0 & $83,33 \%$ & $100,00 \%$ \\
P-16 & 11 & 3 & 1 & $78,57 \%$ & $91,67 \%$ \\
P-17 & 12 & 1 & 0 & $92,31 \%$ & $100,00 \%$ \\
P-18 & 7 & 0 & 5 & $100,00 \%$ & $58,33 \%$ \\
P-19 & 5 & 1 & 1 & $83,33 \%$ & $83,33 \%$ \\
P-20 & 6 & 0 & 0 & $100,00 \%$ & $100,00 \%$ \\
P-21 & 5 & 0 & 1 & $100,00 \%$ & $83,33 \%$ \\
P-22 & 8 & 1 & 2 & $88,89 \%$ & $80,00 \%$ \\
P-23 & 10 & 2 & 0 & $83,33 \%$ & $100,00 \%$ \\
\hline \hline
\end{tabular}




\begin{tabular}{cccccc}
\hline \hline $\begin{array}{c}\text { Kode } \\
\text { Pengujian }\end{array}$ & $\begin{array}{c}\text { True } \\
\text { Positives }\end{array}$ & $\begin{array}{c}\text { False } \\
\text { Positives }\end{array}$ & $\begin{array}{c}\text { False } \\
\text { Negatives }\end{array}$ & Presisi & $\begin{array}{c}\text { Sensitivi- } \\
\text { tas }\end{array}$ \\
\hline P-24 & 6 & 1 & 4 & $85,71 \%$ & $60,00 \%$ \\
P-25 & 12 & 1 & 0 & $92,31 \%$ & $100,00 \%$ \\
P-26 & 12 & 0 & 0 & $100,00 \%$ & $100,00 \%$ \\
P-27 & 6 & 0 & 0 & $100,00 \%$ & $100,00 \%$ \\
P-28 & 6 & 0 & 0 & $100,00 \%$ & $100,00 \%$ \\
P-29 & 10 & 2 & 0 & $83,33 \%$ & $100,00 \%$ \\
P-30 & 9 & 0 & 1 & $100,00 \%$ & $90,00 \%$ \\
\hline \hline
\end{tabular}

Hasil uji coba dapat dilihat pada Tabel 4. Pada skenario pengujian P-01 sampai P-09 menunjukkan smartphone yang diletakan pada kantong baju dan tas memiliki akurasi relatif 20,76\% lebih besar dibandingkan ketika smartphone dipegang. Akurasi yang paling baik pada skenario ini adalah ketika smartphone diletakan di kantong baju yaitu $12,30 \%$ lebih besar dibandingkan ketika smartphone diletakkan di dalam tas.

Sensitivitas aplikasi ketika dipegang berkurang karena posisi tangan yang stabil (mempertahankan titik seimbang) saat guncangan terjadi sehingga vibrasi tidak sebesar dibandingkan pengujian aplikasi jika smartphone diletakkan di tas atau kantong baju. Presisi juga dapat berkurang apabila kondisi tangan tidak stabil (bergerak) saat memegang smartphone sehingga dapat menimbulkan lebih banyak false positif.

Pada skenario pengujian P-10 sampai P-15 menunjukkan akurasi (sensitivitas) threshold $17 / 3$ relatif $8,12 \%$ lebih besar dibandingkan threshold $18 / 2$. Sedangkan presisi pada threshold 17/3 lebih rendah 8,80\% dibandingkan dengan threshold 18/2.

Pada skenario pengujian P-16 sampai P-24 menunjukkan akurasi rata-rata aplikasi pada kecepatan sedang dan cepat lebih besar 8,89\% dibandingkan dengan akurasi pada kecepatan pelan. Akurasi pada kecepatan sedang memiliki akurasi relatif 11,64\% lebih baik dibandingkan pada kecepatan cepat. Pada skenario pengujian P-25 sampai P-30 menunjukkan klasifikasi decision tree meningkatkan rata-rata akurasi (presisi) sebesar $12,18 \%$.

\section{KESIMPULAN}

Kesimpulan yang dapat diambil dari penelitian ini adalah sebagai berikut:

a. Sensor pada smartphone Android dapat digunakan untuk mendeteksi bump.

b. Peta digital dapat menampilkan lokasi bump dan mengestimasi posisinya menggunakan metode clustering pada titik-titik koordinat yang berdekatan

c. Kecepatan dengan akurasi yang baik berdasarkan uji coba adalah pada kecepatan sedang atau cepat.

d. Peletakan posisi smartphone didalam kantong atau tas memiliki akurasi yang lebih baik dibandingkan jika smartphone dipegang karena posisi tangan yang stabil (mempertahankan titik seimbang) saat guncangan terjadi sehingga vibrasi lebih kecil.

e. Algoritma pendeteksi bump yang digunakan adalah Z-Thresh dengan nilai threshold dengan akurasi terbaik sebesar 17 pada batas atas dan 3 pada batas bawah.

f. Dari kombinasi kedua metode tersebut diperoleh nilai akurasi rata-rata sebesar $89.48 \%$.

\section{DAFTAR PUSTAKA}

[1] J. Eriksson, L. Girod, B. Hull, R. Newton, S. Madden and H. Balakrishnan, "The Pothole Patrol: Using a Mobile Sensor Network for Road Surface Monitoring," The Sixth Annual International conference on Mobile Systems, Applications and Services (MobiSys 2008), pp. 2939, 2008.

[2] K. Chen, G. Tan, M. Lu and J. Wu, "CRSM: a practical crowdsourcingbased road surface monitoring system," Wireless Networks, pp. 765-779, 2016.

[3] R. Bhoraskar, N. Vankadhara, B. Raman and P. Kulkarni, "Wolverine: Traffic and road condition estimation using smartphone sensors," 2012 Fourth International Conference on Communication Systems and Networks (COMSNETS 2012), pp. 1 - 6, 2012.

[4] A. Mednis, G. Strazdins , R. Zviedris and G. Kanonirs , "Real time pothole detection using Android smartphones with accelerometers," 2011 International Conference on Distributed Computing in Sensor Systems and Workshops (DCOSS), pp. 1-6, 2011.

[5] T. Zhang, R. Ramakrishnan and M. Livny, "BIRCH: An Efficient Data Clustering Method for Very Large Databases," Proceedings of the 1996 ACM SIGMOD international conference on Management of data, pp. 103-114, 1996.

[6] L. Breiman, J. Friedman, R. Olshen and C. J. Stone, Classification and Regression Tree, Pacific California: Wadsworth \& Brooks/Cole Advanced Books \& Software, 1984. 